\title{
Announcement
}

\section{7th Conference of European Comparative Endocrinologists}

Cordoba, Spain, September 5-10, 1994

This conference will be organized by the Department of Cell Biology of the University of Cordoba (Spain) under the auspices of the European Society for Comparative Endocrinology. The preliminary programme includes invited plenary and symposium lectures as well as sessions of free communications and/or poster presentations on all major fields of vertebrate and invertebrate comparative endocrinology, with special emphasis on cellular, molecular and applied aspects.

For further information, please contact:

Prof. Dr. F. Gracia-Navarro, ESCE Conference Departamento de Biología Celular Universidad de Cordoba Avda. San Alberto Magno s/n E-14004 Cordoba (Spain)

Tel: (34) 57-21 85 94; Fax: (34) 57-21 8634 